\section{The 'abnormal' state: Identity, norm/exception and Japan}

\section{Linus Hagström}

Swedish Institute of International Affairs, Sweden
European Journal of International Relations 20I5, Vol. 2I(I) I22-145

(C) The Author(s) 2014

Reprints and permissions: sagepub.co.uk/journalsPermissions.nav DOI: $10.1177 / \mid 354066$ II35/8356 ejt.sagepub.com

\begin{abstract}
The term 'abnormal' has frequently been used to describe post-war Japan. Together with the idea that the country will, or should have to, 'normalise' its foreign and security policy, it has been reproduced in both academia and Japanese society. Why is Japan branded as 'abnormal', and from where does the desire to 'normalise' it come? Drawing on a relational concept of identity, and the distinction between norm and exception, this article argues that the 'abnormality-normalisation nexus' can be understood in terms of three identity-producing processes: (I) the process whereby the Japanese Self is socialised in US/'Western' norms, ultimately constructing it as an Other in the international system; (2) the process whereby the Japanese Self imagines itself as 'legitimately exceptional' (what is called 'exceptionalisation'), but also 'illegitimately abnormal' - both of which are epitomised by Japan's 'pacifism'; and (3) the process whereby both the Self's 'negative abnormality' and China/Asia are securitised in attempts to realise a more 'normal' (or super-normal) Japanese Self. How Japan is inter subjectively constructed on a scale between 'normal' and 'abnormal' enables and constrains action. Although Japan has not remilitarised nearly as much in the 2000s as is often claimed, these processes might very well forebode an exceptional decision to become 'normal' and therefore more significant steps towards remilitarisation.
\end{abstract}

\title{
Keywords
}

Abnormality, identity, International Relations, Japan, normalisation, norm/exception

\section{Introduction}

Michel Foucault devoted his lecture series at the Collège de France in 1975 to scrutinising the notion of 'abnormal individuals' and its function in modern judicial systems. He

\section{Corresponding author:}

Linus Hagström, Swedish Institute of International Affairs, Box 27035, Stockholm, 1025I, Sweden.

Email: linus.hagstrom@ui.se 
demonstrated how people accused of crimes were subjected to medico-legal investigations, and how their branding as 'abnormal' made them resemble their crimes even before they had committed them (Foucault, 1999: 19). In his introduction to the volume in which Foucault's lectures are published, Arnold Davidson writes:

'Abnormality' has entered our everyday discourse with a conceptual force that seems both natural and inevitable. One can only hope that the next time we are tempted to invoke the label 'abnormal', rather than appearing familiar, this gesture will become problematic, even difficult. (1999: xxv)

Davidson's expression of hope notwithstanding, the label 'abnormal' continues to be invoked quite unwittingly in many different contexts. States and policies, for instance, are sometimes referred to as 'abnormal', and in International Relations (IR) research, the label has been used most persistently to describe post-war Japan and its foreign and security policy.

The aim of this article is to investigate the social construction of Japan's 'abnormality' and the deeply interconnected notion that it is 'normalising', or should have to 'normalise', in the face of security challenges defined in terms of structural and material threats. How is Japan socially constructed as 'abnormal' and in what sense is it deemed in need of 'normalisation'? Moreover, how can one understand the persistence of this 'abnormalitynormalisation nexus', which is ubiquitous both in IR scholarship on Japan and in Japanese foreign and security policy debates? Finally, what are the consequences of this discourse; how does it enable and constrain action?

The continued reproduction of this abnormality-normalisation nexus is particularly puzzling as Japan has continued to maintain significant economic and military capabilities — themselves often-used indicators of 'normality' in international politics — and appears to use those capabilities in ways that are not fundamentally unlike other comparable states. Moreover, Japan is a fully fledged member of international society, and it makes significant contributions to the international organisations where it has membership.

This article argues that the reproduction of the abnormality-normalisation nexus has to be understood as an identity discourse, which produces: (1) Japan as an Other in the international system; (2) the Japanese Self as an Other - at the same time illegitimately 'abnormal' and legitimately 'exceptional'; and (3) Japanese Othering both of its own alleged 'abnormality' and of China/Asia, as a way to secure a more 'normal' Japanese Self. Since the nexus is not based on an objective, absolute standard of 'normality' indeed, since no such standard exists outside 'modes of inquiry' (Foucault, 2000) ideational factors clearly override structural and material ones in conditioning how Japanese foreign and security policy has continuously been understood.

The article investigates the construction and implications of this nexus by employing a relational concept of identity, whereby identity emerges as an effect of boundary production vis-a-vis difference or distinctions between Self and Other (Campbell, 1994, 1998 [1992]; Connolly, 1991; Rumelili, 2004; Wodak et al., 2009 [1999]). It moves beyond the constructivist commonplace that identities and norms are mutually constitutive by elaborating on the way in which norms and exceptions are involved in the construction of 'abnormality' and 'normalisation'. This discussion introduces three processes 
whereby Self is differentiated from Other: socialisation, exceptionalisation and securitisation.

The next three sections serve to establish the understanding that Japan is 'abnormal', which again is dominant both in IR scholarship on Japan and in Japanese foreign and security policy debates. The subsequent section reviews the thesis that Japan is finally 'normalising'. It thereby demonstrates, yet again, that Japan has not been regarded as quite 'normal', and it elucidates the inter subjective, but relative, standard of 'normality' according to which it seems reasonable and even necessary for Japan to 'normalise' its foreign and security policy.

The journey into the academic and political function of the abnormality-normalisation nexus is then followed by a critical discussion of the concept of 'normality', and finally by an analysis of how the nexus, and a Japanese desire for 'normality', has continuously (since the 19th century) been constructed through Japan's differentiation from imaginations of the US/the West on the one hand, and from China/Asia on the other the former process being defined as a case of socialisation, the latter as a case of securitisation; and with aspects of exceptionalisation - namely, the process whereby Self imagines itself as 'exceptional' — entwined in both.

As a by-product of this analysis, a significant part of the literature on Japan's foreign and security policy is critically reviewed and synthesised. Indeed, this literature serves as the main material for the article, and the article thus aims to contribute through a meta-analysis.

\section{'Abnormality', identity and norm/exception}

To Foucault, the construction and diffusion of the category of the 'abnormal' reflects the dividing practice whereby ideas about what is 'normal' get established and become dominant. In other words, the 'normal' is defined through differentiation, and turned into something identifiable and indeed desirable and even coercive, precisely by invoking the 'abnormal', and the same logic applies when the 'mad', the 'sick' and 'criminals' are differentiated from the 'sane', the 'healthy' and the 'good boys' (Foucault, 2000: 326). The reproduction and internalisation of these categories ultimately constitute interpretative dispositions; they define what is conceivable and what is inconceivable, and therefore underlie processes whereby human beings fashion themselves and others into subjects. To Foucault, these kinds of dividing practices are the essence of power defined as 'productive', but they are clearly also fundamental to identity construction (2000; cf. Digeser, 1992).

In fact, constructivist and poststructuralist research in IR tends to conceptualise identity in a highly related fashion. States are believed to be formed, maintained and transformed most fundamentally through discursive dividing practices (Williams, 1998: 205). As Bahar Rumelili succinctly argues, 'Identities are always constituted in relation to difference because a thing can only be known by what it is not' (2004: 29). To David Campbell, this is the gist of 'foreign policy', which is then 'understood as referring to all relationships of otherness, practices of differentiation, or modes of exclusion that constitute their objects as foreign in the process of dealing with them' (1994: 150).

Since the presumed 'normal' is constituted importantly through differentiation vis-avis the presumed 'abnormal', and since the branding of some states as 'abnormal' and others 
as 'normal' epitomises Campbell's 'foreign policy', it seems both reasonable and meaningful to try to transpose Foucault's gaze of the 'abnormal' to the realm of IR. Yet, are states not rather different from Foucault's individuals? It is true that states seem more difficult to discipline and appear to have more room for manoeuvre than individuals, but both are ultimately social actors, which are produced and sustained though inter-subjective meanings and practices (cf. Jackson, 2004; Epstein, 2010). The rest of this section will theorise three discrete, yet highly interrelated, processes whereby the distinction between the 'normal' and the 'abnormal' is socially constructed. It does so by drawing on 20th-century German legal scholar Carl Schmitt's closely related distinction between 'norm' and 'exception'.

First, the concomitant reproduction of inter-subjective standards of 'normality', and desires and pressures to be 'normal', could be conceptualised as a process of 'socialisation' - socialisation in IR being defined as 'the process by which states internalize norms originating elsewhere in the international system' (Alderson, 2001: 417; cf. Flockhart, 2006). Defined in such terms, with a clear focus on the diffusion of norms, socialisation is compatible with the notion that norms constitute identities (Katzenstein, 1996b), or that the two are 'mutually constitutive' (Wendt, 1992). Yet, one could argue that this definition of socialisation focuses too much on norms, and too little on exceptions, at least to be fully compatible with the relational understanding of identity. Schmitt (2004 [1922/1934]: 15) argued: 'The exception is more interesting than the rule. The rule proves nothing; the exception proves everything: It confirms not only the rule but also its existence, which derives only from the exception.' While Schmitt's primary interest admittedly was exceptions that repeal norms, in Foucauldian terms, the implication is rather that exceptions confirm norms. Hence, even norms that constitute identities are dependent on the prior invocation of exceptions. Socialisation is a case in point, because the norms or standards of 'normality' that states 'internalise' (Alderson, 2001) require a constitutive 'outside' — importantly, the presumed 'abnormal'.

Second, Schmitt argued that the capacity to decide on the exception defines state sovereignty. In a similar vein, exceptionalism ultimately characterises the production of boundaries between states (nations, groups, etc.). By establishing what the state 'is' and what it 'is not', it appears in all its supposed exceptionality. Indeed, exceptionalism, or a sense of 'positive uniqueness', is a defining characteristic of nationalism (Smith, 1991). This is clearly a key aspect of the relational concept of identity; again, identity is known crucially by what it 'is not', that is difference. R.B.J. Walker (2006: 58) notes, 'subjectivity ... produces its own exteriority as object'. Indeed, he argues that 'there must be no reduction of (legitimate) differences in order to attain universality, for otherwise we arrive not at a states system, an international, but at an empire, whether understood as "humanity" or "imperium"' (2006: 61). The reproduction of 'diversity within unity' (2006: 61) — of 'positive'/'legitimate' uniqueness or exceptionalism - is a process referred to here as 'exceptionalisation'. The category of the 'abnormal', in contrast, exemplifies 'illegitimate' difference, or 'diversity without unity'.

Third, this 'illegitimate' or 'negative' difference is defined as 'a case of extreme peril, a danger to the existence of the state, or the like' (Schmitt, 2004 [1922/1934]: 6), or, in Schmitt's terminology, as 'the exception' (2004 [1922/1934]: 6), or as 'enemy' in contrast to 'friend' (1996 [1932]: 26-27). Schmitt's idea that 'he' 'who decides on the exception' is 'sovereign' (1996 [1932]: 5) means that 'he' both 'decides whether there is an 
extreme emergency' and 'what must be done to eliminate it' (1996 [1932]: 7). The social construction of threats and enemies to legitimise exceptions - 'emergency measures' or 'actions outside the normal bounds of political procedure' — is precisely the gist of 'securitisation' (Buzan et al., 1998: 23-24). However, enemies, exceptions and difference stand in 'double relation' to friends, norms and identity, in that they both threaten and constitute them. As William Connolly argues:

madness or unreason or ... severe abnormality is doubly entangled with the identity of the rational agent and the normal individual: it helps to constitute practical reason and normality by providing a set of abnormal conducts and 'vehement passions' against which each is defined, but it also threatens them by embodying characteristics that would destabilize the normal if they were to proliferate (1991: 67).

By expanding on the relationship between norm and exception, the preceding paragraphs illuminate three processes whereby Japan's abnormality-normalisation nexus, and identities more generally, are relationally constituted: (1) socialisation operates through Self's emulation of dominant norms - norms which fundamentally depend on prior exceptions; (2) exceptionalisation operates through Self's production of 'legitimate' differences vis-a-vis Others; and (3) securitisation operates through Self's attempts to protect itself from 'illegitimate' or 'threatening' difference.

The relational concept of identity is thus fundamental, but the study of foreign and security policy often sets out from another, rather different, plane - if it takes identity seriously at all, that is. Instead of problematising the objects of study by delving into their processes of becoming, many studies just take them for granted and further reify them by treating their foreign and security policies as the courses of action of secure and ahistorical, or at least well-confined and highly resilient, entities, and logically posterior to their existence. As such, identity is believed to define national interests, which in turn cause foreign and security policy. In other words, identity is treated as the independent variable, and behaviour as the dependent one. This understanding of identity has arguably become a 'necessary routine in constructivist writings' (Berenskoetter, 2010; see also Hopf, 2002; Katzenstein, 1996b; Wendt, 1999; for a critique, see Zehfuss, 2001).

Although the relational concept of identity has tended to play an analytical role reminiscent of a dependent variable, nothing prevents it being linked to the primary mission of identity in the other sense, namely, to ascertain what foreign and security policies become more or less likely given certain identity constructions, or what courses of action processes of differentiation enable and constrain (Doty, 1993; Milliken, 1999). Thus, even if states are constructions of the imagination that come into 'being' through inter-subjective meanings and practices of differentiation, for example, 'foreign and security policy', on another level, it is perfectly reasonable to enquire what policies become conceivable, communicable and coercive in the light of such differentiation (Holland, 2013). Different constructions of identity are thus believed to correlate with distinct ranges of 'imaginable conduct' (Doty, 1993: 299); a Japan understood as 'abnormal' or 'pacifist' is believed to have different propensities for action from one that is understood as 'normalising' or 'normal'. 


\section{The IR debate: 'Pacifist' Japan, 'abnormal' Japan}

With Japan's agglomeration of economic capability in the post-war period, it was dubbed an economic 'great power' or 'superpower'. Since realists believe that the anarchical international system moulds security- or power-maximising 'territorial states', a great number of observers more or less explicitly influenced by realism expected Japan to exercise commensurate political and military power, or to become a fully fledged great power. However, since Japan continued to punch below its weight in their accounts, the notion spread that it was an 'anomaly' or simply 'abnormal' (Kennedy, 1994; Layne, 1993; Waltz, 1993, 2000).

Japan's 'abnormality' is epitomised by Article 9 of the post-war constitution, in which the state famously relinquishes its sovereign right to wage wars and to use force or the threat of force 'as means of settling international disputes', and establishes that it will not maintain 'land, sea, and air forces, as well as other war potential' (Constitution of Japan, 1946). In Schmittean terms, the inability 'to declare an exception' is exactly what makes Japan 'abnormal'; indeed, to Schmitt (2004 [1922/1934]: 11), it would even disqualify Japan from enjoying the status of a state.

When Japan seemed to defy realism, it became obvious how dominant realist assumptions are in scholarly, media and policy discourses on Japan's foreign and security policy. The evidence is that Japan began to be ascribed several other identities than the 'normal' one prompted by realism - to name just a few, those of a 'trading state' (Rosecrance, 1986), an 'economic' and a 'civilian' power (Funabashi, 1991/1992; Maull, 1990/1991), and a 'reactive' and 'defensive' state (Calder, 1988, 2003; Pharr, 1993). Also, many observers - not all self-proclaimed realists - continued to reproduce the image of Japan as an economic 'giant' and a political and military 'pygmy' (Funabashi, 1991/1992: 65; Inoguchi, 1991: 1). In more recent years, Japan has moreover been called, among others, an 'aikido state' (Hook et al., 2001), a 'soft power superpower' (Watanabe and McConnell, 2008) and a 'cultural power' (Otmazgin, 2008).

Some observers have attempted to 'normalise' Japan's allegedly one-sided pursuit of 'economic' or 'civilian' power, claiming for instance that it is the result of economic rationality (Rosecrance, 1986). Identity first became the explicit focus in such attempts in the 1990s. Thomas Berger and Peter Katzenstein tried to resolve the 'abnormality' allegedly at the heart of Japan's international relations by attributing a 'pacifist' or 'antimilitarist' identity to it, either directly or through a focus on what is believed to be that identity's constitutive parts, namely, an 'antimilitarist culture' in Berger's (1993, 1996, 1998) version and 'peaceful cultural norms' in Katzenstein's (1996a) version (cf. Katzenstein and Okawara, 1993). The (mostly US) scholars associated with this literature have become known as constructivists for their emphasis on norms and culture as factors shaping Japan's foreign and security policy. The arguably most important example is, again, Article 9 of the constitution (Berger, 1998; Katzenstein, 1996a, 2008; Tadokoro, 2011; Tsuchiyama, 2007).

The constructivist approach to Japan has later encountered criticism from scholars who wanted to save realism (albeit not necessarily Kenneth Waltz's version of neorealism). In short, this heterogeneous group contends that post-war Japan's foreign and security policy could be readily explained from the perspectives of 'mercantile realism' (Heginbotham and Samuels, 1998), 'postclassical realism' (Kawasaki, 2001) and 'defensive realism' (Lind, 2004; Midford, 2002; Twomey, 2000). The aim of each of these accounts is to argue that 
Japan in fact labours under the same structural and material constraints as other states, albeit with some atypical implications. However, the ascription to Japan of new identities, such as that of a 'circumscribed balancer' (Twomey, 2000) and a 'buck-passer' (Lind, 2004), shows that these realists also do not consider the country completely 'normal'.

Still others have gone along with the notion of Japanese 'pacifism' or 'antimilitarism', while explicitly arguing that such ideational factors have structural and material bases. Yasuhiro Izumikawa (2010), for instance, holds that Berger's 'antimilitarism' really has three other constitutive elements than 'an antimilitarist norm', that is, 'pacifism', 'antitraditionalism' and 'fear of entrapment'. In particular, the latter (together with 'fear of abandonment' - although the term is absent in Izumikawa's analytical framework) is found to be most congruent with Japan's post-war security policy. Akitoshi Miyashita (2007) also tries to turn the tables on constructivism by arguing that the sustainability of antimilitarist norms in Japan can be explained to a large degree by 'structural and material factors', such as 'threat perceptions', Japan's 'economic prosperity', 'political stability' and particularly the security alliance with the USA. However, the importance that these two accounts attach to 'fears' and 'perceptions' is problematic, unless they view such states of mind as direct effects of structural and material factors.

In fact, even the US constructivists attributed importance to structural and material factors. Although they believed norms and culture to transform very slowly, and thus saw them as unlikely to bring about radical change in Japan's foreign and security policy in the short to medium term (e.g. Berger, 1993, 1998; Katzenstein and Okawara, 1993), they still predicted that change would eventually come about as a result of changing structural and material conditions. Berger (1993: 120; 1998: 209), for instance, held that any potential change that might occur in the future would have to take place as the result of an external 'shock', such as a weakened alliance with the USA and/or the emergence of a serious regional security threat. Katzenstein and Okawara (1993: 117), in turn, argued that potential change in the future might rather be explained by 'domestic determinants', but they also assigned some explanatory force to 'discontinuities in the international system'. In more recent years, Andrew Oros (2007: 4) has claimed that the medium- to long-term sustainability of Japanese antimilitarism is 'determined in part by the security environment in East Asia and the world' (cf. Friman et al., 2006; Soeya et al., 2011). Hence, even if ideational factors were seen as temporarily playing a role in Japanese foreign and security policy, these constructivists believed that Japan would ultimately have to conform - more 'normally' - to structural and material factors.

The debate between the US constructivists and their critics is often framed in terms of a tug of war between ideational factors and structural/material ones, but this section serves to note the similarity between the two positions - indeed, to emphasise how they share the notion that Japan will eventually have to remilitarise as a result of structural and material factors.

\section{Japanese identity politics: 'Abnormal' versus 'exceptional' Japan}

As noted above, post-war Japan has often been ascribed a 'pacifist or 'antimilitarist' identity. Many works emphasise that the Japanese people started to adopt a rather inward-looking 'one-country pacifism' (ikkoku heiwa shugi) after the war. To the 
incumbent centre-right Liberal Democratic Party (LDP), Japan was already a 'peace state' (heiwa kokka), and to parties on the political left centring on the (now defunct) Japan Socialist Party (JSP), it should become one, although these parties constantly complained that political practice strayed problematically from the pacifist constitution. According to James Orr, the peace movement was founded on two other identityrelated pillars, namely, 'the victim experience arising from wartime suffering' and 'the victimizer experience as supporters of the war of aggression', although by the 1960s the victim identity had allegedly become dominant (2001: 3; cf. Buruma, 2009 [1994]; Igarashi, 2000).

In the pacifist narrative, 'pacifism' would make post-war Japan exceptional - a conviction that arguably underlay the emergence of a certain 'peace nationalism', or 'a new sense of national purpose' in the post-war era (McVeigh, 2004: 207). It also resonated with the vast nihonjinron ('theory of the Japanese') discourse, which constructs the Japanese people as inherently 'harmonious' and 'peaceful' (Befu, 2001; Dale, 1986; Oguma, 2002). To the centre-left, pacifism was thus exceptionalised into something that would make Japan legitimately different from other countries.

To the radical parts of the political right, in contrast, the 'pacifist identity' made Japan illegitimately different and dangerously 'abnormal'. The term 'abnormal' (ijō or futsū de wa nai) is not always used in Japan (although examples of its use include Araki, 2005; Kitaoka, 2000), but 'abnormality' is implied, for instance, when politicians and pundits call Article 9 a 'big obstacle' (shōgai or ōkina shishō) (Kitaoka, 2000: 271; and Yachi, 2009: 124, respectively), and when they criticise Japan's security policy for being 'insufficient' (fujūbun) (Kitaoka, 2000: 11; Yachi, 2009: 123). Although governments formed by the long-reigning LDP have tended to pay lip service to a notion of 'pacifism', throughout the post-war period, party manifestos continued to argue that Japanese security could only be safeguarded by revising Japan's constitution (Hook, 1996; Ryu, 2007; Soeya et al., 2011).

This serves to problematise the reasonableness of ascribing Japan a 'pacifist' identity in the first place. The lowest common denominator of different political agendas instead appears to be a narrative of difference; Japan is portrayed as an Other in the international system, albeit with totally different connotations and implications - exceptionalisation of Japan's 'pacifism' on the political centre-left, and securitisation of Japan's threatening 'abnormality' on the political right. Moreover, the 'Peace Constitution' epitomises Japan's difference in both contexts, and calls for the country to 'normalise' typically centre on the issue of revision of the constitution (Hagström, 2010).

Glenn Hook's $(1988,1996)$ research is often grouped together with Berger's and Katzenstein's as 'constructivist' (e.g. Izumikawa, 2010), but it actually takes a more flexible approach to Japanese demilitarisation and remilitarisation. It finds that Japan began to remilitarise as early as during the Allied occupation (1945-1952), and that many antimilitaristic principles eroded in the 1980s as a result of external and internal pressures. In fact, the Japanese foreign and security policy debate has been divided in rather the same way as IR research as regards how to understand Japan's role in the world. In Soeya Yoshihide's account, the lingering antagonism between two opposing identities — one 'pacifist' (heiwa shugi) and one 'traditional statist' (dentōteki kokka shugi) — has given Japan a 'dual identity' (nijū aidentitī) and resulted in a prolonged 
identity crisis (Soeya, 2005). The notion that contradictory forces have been operating in post-war Japan is also at the root of the idea that Japan's post-war identity has been 'ambiguous' (Tamamoto, 2003: 195).

Feeding the division within the realm of Japan's foreign and security policy, moreover, has been profound contestation over how Japan should deal with its militaristic and imperialistic past (Bukh, 2007; Buruma, 2009 [1994]; Shibuichi, 2005). In right-wing narratives, a 'normal' Japan, and to an even greater extent a super-normal — militarily 'normal' but culturally exceptional — 'beautiful' (utsukushii) (Abe, 2006), 'correct' (tadashii) (Hiranuma, 2007) or 'strong' (tsuyoi) (Tamogami, 2011) country, is defined both in terms of remilitarisation and of not having anything to be ashamed of or apologise for. In fact, the latter is arguably what enables the former. Yet, these goals are not necessarily compatible, because recurring attempts on the part of some actors to make Japan more 'normal' in the second sense are what makes it difficult for the world to accept a more 'normal' Japan in the first sense (Lawson and Tannaka, 2011; Zarakol, 2010).

The bottom line is to reinforce the point that the post-war era has seen a constant tug of war between parallel forces working towards the strengthening versus the abolishing of 'pacifism'. Although narratives of 'exceptionalism' and 'abnormality' are diametrically opposed, they are both conditioned on a notion of Japanese 'difference', and so is the political right's replacement idea that Japan should become 'beautiful', 'correct' and 'strong'.

\section{The tendency: Japan's 'normalisation' or 'remilitarisation'?}

As seen above, Japan's political right has long had the ambition to fundamentally alter the country's foreign and security policy — and this position was further strengthened after the near-extinction of the political left in the 1990s. There has been an equally resilient prophecy among scholars that such radical change would, or should have to, occur. Yet, it was not until the early 2000s that a critical mass of Japan-watchers started to argue in rather bold terms that Japan had begun to 'normalise' its foreign and security policy, or to 'remilitarise' (Arase, 2007; Hughes, 2009a; McCormack, 2004; Pyle, 2007; Samuels, 2007; Tadokoro, 2011; Tanter, 2005; Tsuchiyama, 2007).

Katzenstein and Okawara contended in 1993 that:

normative constraints have made it impossible to revise Article 9 of the Constitution; to build nuclear weapons or to agree to their deployment on Japanese soil; to dispatch Japanese troops abroad in combatant roles even as part of an international peacekeeping force; to sell weapons abroad; or to raise the JDA [Japan Defense Agency] to ministerial status. (1993: 104)

Yet, 20 years later, one can discern more or less change in each of these issue areas (Hagström and Williamsson, 2009).

Furthermore, in 1996, Berger wrote that Japan 'eschewed obtaining weapons systems that might be construed as being offensive in character, such as aerial refuelling capacity or helicopter carriers' (1996: 351). This has also changed in the 2000s, as the SelfDefense Forces (SDF) have recently procured two 13,500-ton Hyuga-class helicopter destroyers and one 20,000-ton DDH-22 helicopter carrier, and have acquired in-flight 
refuelling capability by purchasing four multipurpose Boeing KC-767 tankers (Hagström and Williamsson, 2009).

Japan's 'normalisation' or 'remilitarisation' has been explained most importantly with reference to the necessity of countering a North Korean 'threat', balancing a 'rising China' and avoiding 'US abandonment' (Pyle, 2007; Samuels, 2007). This again implies the long-overdue comeback of structural and material factors to 'limit the impact of other, more idealist, and value-based role identities' on Japanese foreign and security policy (Catalinac, 2007: 91). Yet, this explanatory model presupposes and reproduces a certain standard of 'normality' in IR, and each of its components could be criticised and alternative interpretations proposed.

First, while new goals and problems have been articulated in Japan's foreign and security policy in the past decades, and more advanced policy instruments have been obtained, these changes have seemed to occur within a hitherto stable core interpretation of Article 9 of the Japanese Constitution, and without big shifts in the Japan-US alliance. In other words, since this means that Japan's international orientation has remained largely intact throughout the post-war period, the interpretation that the country has 'remilitarised' does not seem reasonable (Hagström and Williamsson, 2009; cf. Oros, 2007; Soeya, 2011).

Second, North Korea does not appear to fit realist criteria for 'objectively' measuring threats. Although over one million people serve in the North Korean armed forces, as far as is known, its military aircraft and naval ships have hardly improved at all in the past few decades (Hagström and Turesson, 2009; Hughes, 2009b; Smith, 2007). The possible exception to this state of stagnation is North Korea's notorious missile and nuclear programmes. However, tests thus far have not really proved the quality of these weapon systems (Crail and Kimball, 2012), and it is as yet unclear how far Pyongyang is from developing the technology to miniaturise nuclear payloads (Richardson, 2013). Moreover, although the North Korean rhetoric sounds belligerent, it could also be interpreted as strongly defensive (Hagström and Turesson, 2009). Interestingly, the Japanese construction of North Korea as a threat also does not primarily invoke North Korea's development of weapons systems, but rather Pyongyang's abduction of some 17 Japanese nationals in the 1970s and 1980s — what is known as the 'abduction issue' (Hagström and Hanssen, under review).

Third, the interpretation of China's 'rise' is most commonly based on the enormous increases in its gross domestic product (GDP) and defence spending since the 1970s. However, Brendan Howe (2010: 1326) argues that the threat 'objectively' posed to Japan by the Soviet Union was far greater than that currently posed by the 'rising China'. Moreover, although Japanese policymakers tend to construct China's 'rise' as a threat (Hagström, 2008/2009; Hagström and Jerdén, 2010), it does not seem reasonable to interpret Japan's China policy over the period 1978-2011 as a case of 'balancing'. Tokyo could rather be interpreted as having facilitated the successful implementation of China's grand strategy, and hence as having 'accommodated' the rise of China (Jerdén and Hagström, 2012).

Masaru Tamamoto (2004: 12) has commented that 'radical change in the Japanese public attitude toward military security seems disproportionate to the threat'. Hence, the persistent reproduction in various discourses in the past decade of the image that North 
Korea and China are threats to Japan has to be understood as a case of securitisation. As Roxanne Lynn Doty (1993: 316) argued in a different but parallel case, "the attributes attached to the subjects of this discourse are not reflections of "reality" but rather illustrations of the inextricable linkages between the discursive production of "knowledge" and the power inherent in that production'. In other words, 'structural and material factors' do not have extra-discursive meaning, but are attributed meaning through the involvement of ideational factors. Now, this is not to argue that armed conflict in East Asia is inconceivable; it is just to caution against the logic that threats can be deduced unproblematically from a configuration of capabilities, plus an ascription of intentions (cf. Buzan et al., 1998). Rather the contrary, the conceivability of armed conflict depends on how reality and knowledge are socially constructed.

That a Japanese identity change might be in the offing, and affect both how 'threats' are socially constructed within Japan, and how scholars interpret Japan's foreign and security policy, is suggested by Amy Catalinac's (2007: 82-86) findings. She demonstrates that the number of Japanese Diet members who hold 'pacifist' and 'pragmatic multilateralist' role conceptions decreased between the Gulf War in 1991 and the US War in Iraq in 2003 , from $46 \%$ to $16 \%$, and from $40 \%$ to $29 \%$, respectively. Over the same period, the proportion of those with a 'centrist' role conception increased from $14 \%$ to $55 \%$, and this is essentially a 'role identity [that] prescribes realpolitik behavior for Japan' (Catalinac, 2007: 91). Other scholars have similarly argued that the role conceptions of 'global player', 'global ordinary power' or 'international state' have gained momentum in the post-Cold War period and superseded the 'peace state' or 'pacifist' security identity (Inoguchi and Bacon, 2006; Ryu, 2007; Singh, 2008, 2011). Soeya's devising of a 'middle power' identity for Japan is a case in point. It could be interpreted as envisioning a compromise between competing 'pacifist' and 'traditional statist' identities (Soeya, 2005).

This section has served to problematise the notion that Japan has 'remilitarised' to the extent suggested by the scholarly debate in the 2000s. Yet, that debate has presupposed and reproduced a worldview according to which it seems reasonable and even necessary for Japan to remilitarise. The power of this worldview is suggested by the observation that an identity change appears to be under way. Constitutional revision, for one, is the linchpin of current Prime Minister Abe Shinzō's political agenda.

\section{On 'normality' and Japanese identity}

The preceding sections have demonstrated the centrality of the abnormality-normalisation nexus to discourses on Japan's international relations. David Welch (2011: 18) recently wrote that the debate about whether Japan is or should become a 'normal' state is 'fundamentally about national strategy'. Yet, one contribution of this article is to demonstrate that it is a discourse through which Japanese identity is formed, maintained and transformed, both as Self and as Other. Hook (1996: 76) is one of few previous scholars who have discussed a connection between identity and 'normality', but since he took 'identity' to mean 'antimilitarist identity', he basically construed a relationship characterised by contradiction. Since Japan's 'antimilitarist' or 'pacifist' identity continues to be securitised as dangerously 'abnormal' among the 
growing Japanese political right, and to be exceptionalised as positively different on the shrinking centre-left, it seems more fruitful to consider the relationship between 'normality' and identity as one of constitution. As discussed above, inter subjectively held ideas about the former constitute the latter as either contradicting or emulating the norm, and contradicting the norm either by threatening it or by surpassing it.

But what then is the norm - what is the inter-subjectively held standard of 'normality'? Political heavyweight Ozawa Ichirō, who is often credited with having popularised the term 'normal country' (futsū no kuni) in the Japanese context (Kitaoka, 2000: 10), has suggested that Japan could only become 'normal' by: (1) revising Article 9, and thereby retrieving the ability to exercise the right of collective self-defence; (2) dispatching the SDF to participate in United Nations (UN) peacekeeping operations; and (3) gaining a permanent seat on the UN Security Council (Ozawa, 1993). In more recent years, a 'normal country' has been defined by scholars as one that is constitutionally able and prepared to deploy military force for national and international security ends, in particular, for the purpose of collective self-defence (Hirata, 2008; Kitaoka, 2000; Soeya, 2011; Soeya el al., 2011; Tadokoro, 2011; Tanter, 2005). Oros (2007: 3) defines 'normal' as an 'independent fully armed great power', and Richard Samuels (2007: 111) clarifies that "stripped to its essence, the idea of a "normal nation" simply means a nation that can go to war' (cf. Lummis, 2007). In the last resort, 'normality' usually hinges on the possession of nuclear weapons (Tanter, 2005; Waltz, 1993). And the United Kingdom is often alluded to as a model of sorts (Inoguchi and Bacon, 2006; cf. Hughes, 2007).

This article argues that any standard of 'normality' is a social construction, which requires the 'abnormal' to demarcate the limits of its own domain. The article represents the first consistent critique of the dominant standard of 'normality' in the context of Japan's foreign and security policy, although bits and pieces of this criticism have previously appeared elsewhere. Most importantly, scholars have tried to problematise this standard of 'normality' by arguing: (1) that the (rest of the) world should not necessarily be seen as 'normal' (Hook, 1996); (2) that a 'nationalism-as-normal model of state identity' underlies most ascriptions of 'normality' and that 'Japan's problem in becoming "normal" is at least partly due to the continuing prevalence of this model' (Lawson and Tannaka, 2011: 421); (3) that Japanese pacifism should rather be regarded as the model 'for others to emulate' (Lawson and Tannaka, 2011: 421-422; cf. Lummis, 2007); (4) that most 'normal', or average, states are in fact poor and weak and lose whatever wars they engage in (Lummis, 2007); and (5) that the Japanese foreign and security policy could - in a sense (and for what it is worth) — be considered 'normal' already, because it is similar to that of other comparable states (Hagström, 2005a, 2006, 2009; Howe, 2010).

By arguing that " $\mathrm{t}]$ he question is not what is "normal" in the abstract, but what is considered normal by Japan, and by Japanese', Oros (2007: 3) might also seem to challenge dominant standards of 'normality'. However, unlike the works quoted in the previous paragraph, his observation lacks an understanding that what is 'considered normal by Japan, and by Japanese' is a product of social construction, and hence an effect of productive power. While it is true that "'normality" is what states make of it' (Lawson and Tannaka, 2011: 421), the implication is not that the Japanese are free to choose whatever they want. There are strong systemic pressures precisely for Japan to 'deviate from what 
has been "normal" for itself in terms of its pacifist credentials' (Lawson and Tannaka, 2011: 421) because, as noted above, that 'normality' is socially constructed as deviancy

— both in IR scholarship and in Japanese foreign and security policy debates.

According to Harumi Befu, there is also a more general Japanese tendency towards self-castigation through the acceptance of a 'Western-centric scheme of the universe' and an embrace of 'Westerners' value judgments of Japan's backwardness' - what he calls 'auto-Orientalism' (2001: 128; cf. Yoshino, 1992). The next section explores this matter further by returning to the question of how to understand the persistence of Japan's nexus of abnormality-normalisation, in particular, by analysing how it is constructed through Japan's differentiation from imaginations of the USA/West and China/Asia the former defined as a case of socialisation and the latter as a case of securitisation.

\section{Japanese identity and difference}

Many works, transcending the realm of foreign and security policy, agree that Japanese identity has been inter subjectively constructed against the backdrop of two rather different imaginations of difference: one of the USA/West and the other of China/Asia (Hosoya, 2012; Oguma, 2002; Yoshino, 1992). This is arguably another source of its alleged 'ambiguity' (Kösebalaban, 2008; Oguma, 2002; Tamamoto, 2003; cf. Zarakol, 2010).

Observers outside the field of IR argue that up until the Meiji Restoration in 1868, Japanese identity was constructed primarily by differentiating Japan from Asia, and particularly China. The kokugaku (literally, 'the study of [our] country') of the 18th and early 19th centuries is one prominent body of literature which contrasted a 'masculine' and 'superior' Japan with a 'feminine' and 'inferior' China (Befu, 2001: 123-125; Igarashi, 2000: 35-36; Tanaka, 1993: 3). Kazuki Sato (1997: 122) describes how a representation of the Chinese as 'poor, dirty and penny-pinching' started to spread in the latter half of the 19th century, and how it played a role in the growth of Japanese nationalism. The notion of 'civilisation' (bunmei) gained importance around this time, and Tessa Morris-Suzuki (1998: 28) points out that it 'allowed difference to be transposed from the realm of space to the realm of time, so that "foreignness" increasingly came to be interpreted as "underdevelopment".

After the Meiji Restoration, as Japanese leaders aspired to catch up with and get recognition from European powers and the USA, the 'civilised West' replaced China as the main object of differentiation (Guillaume, 2011: 86). This change of focus is often represented by the spread of slogans such as 'Leave Asia, Enter Europe' (datsua nyūō) from 1885 (Tanaka, 1993: 55). Eiji Oguma (2002: 71) notes that Britain, in particular, functioned as role model in the late 19 th and early 20 th centuries.

Around the time of Japan's aggression in China in the early 20th century, however, Japanese discourses again began to focus on the neighbour. China was now being viewed as Japan's past — the 'idealized space and time from which Japan [had] developed' (Tanaka, 1993: 12) — and new concepts, such as 'Same Script/Culture, Same Race' (dōbun dōshu), were coined to emphasise similarities between the two. Yet, Sato (1997: 131) argues that the notion of dóbun dosshu was contested at the popular level from the very beginning, and that the portrayal of the Chinese as 'a strange, different and inferior 
race' continued to contrast with presumably superior Japanese qualities. The tension between the conflicting goals of Japanese superiority and Pan-Asianism was arguably dissolved through the notion that Japan should 'express its paternal compassion and guidance' (Tanaka, 1993: 108), or 'raise Asia' (kōa).

While many agree that Japanese discourses in the early 20th century positioned Japan between the West and Asia, Kuniko Ashizawa (2008: 589) argues that Japan's 'eventual choice was Asia in an extreme manner in the 1930s and 1940s, which resulted in the country entering into a devastating war and experiencing complete defeat'. However, it seems more plausible, perhaps, to interpret Japan's war as part of the aspiration to become a Western imperialistic power - that is, a 'normal, civilised great power' by the yardstick of the time - and, hence, that Japan 'chose' the West. In other words, Japanese notions of 'civilisation' and 'normality' were by-products of Japan's encounter with, or socialisation into, 'international society', or 'modernity' more generally (Bukh, 2009, 2010; Suzuki, 2005, 2009; Zarakol, 2010, 2011). At the same time, Ashizawa is correct to the extent that Japan's war was enabled by the notion that Asia was somehow substandard, or illegitimately different, and therefore in need of guidance.

After the defeat in 1945, the USA continued to play the role of idealised difference against which Japanese identity was defined (Befu, 2001; Bukh, 2010; Guillaume, 2011; Igarashi, 2000; Tamamoto, 2003). According to Yoshikuni Igarashi's (2000: 35-36) analysis, the narration of relations was again gendered, but Japan had now been displaced by the USA as performing the 'male role', and it had succeeded Asia as playing the 'female' one. Hence, the imagined USA/West kept functioning as a mirror image against which Japanese identity (or rather difference) appeared in both a positive and a negative light — again, as 'exceptional' and 'abnormal', respectively (cf. Befu, 2001). The desire for 'Western normality', moreover, also surfaced in societal realms other than foreign and security policy, for example, the politics of leisure (Leheny, 2003).

Although Japan has remained an important Other in Chinese (and Taiwanese) narratives in the post-war period — not least ones related to history (Gustafsson, 2011; Hwang, 2010; Sejrup, 2012; Suzuki, 2007) - very few works speak of China as an object of collective Japanese imagination in the post-war period (Kano, 1976, is one exception). Only when it began to appear obvious that the Chinese modernisation drive from 1978 onwards had succeeded did China again start to loom larger in Japanese discourses (Hosoya, 2012; Togo, 2012; quite as predicted by Oe, 1995; and Befu, 2001). Although the overarching differentiation mechanism has remained within the framework of emphasising Japanese superiority and Chinese inferiority, Kai Schulze (2013) argues that the concrete expressions of that differentiation changed as the Chinese economy grew stronger and eventually surpassed the Japanese as second biggest in the world in 2010. Hence, when China was perceived to enter Japan's domain of economic power, that very same quality ceased to be a unique marker of Japan, and so Japanese discourses instead began to emphasise Japan's pre-eminence in terms of ideas and values.

Rumi Sakamoto (2007: 85) finds a frequent juxtaposition of Japan's 'mature democracy' and 'healthy nationalism' with China's 'lack of democracy' and 'childish nationalism', and notes that it is essentially a modern version of the old contrast between 'civilised' Japan and 'uncivilised' China. Other authors demonstrate that even opposing positions in the Japanese political discourse on China share an understanding of China as 
opaque, unstable and potentially threatening (Hagström and Jerdén, 2010). In particular, the securitisation of China as increasingly 'aggressive' and 'assertive' in recent years has come to be used in arguments for the further 'normalisation' of Japanese foreign and security policy (Hagström, 2012), and so has the image of China as being 'anti-Japanese' (Gustafsson, under review).

Just as in the Meiji era (1868-1912), rather different processes of differentiation thus appear central to the construction of Japanese identity in the present. On the one hand, there is a lingering ideational hierarchy where the imagined USA/West continues to be ascribed the 'normality' against which Japan's 'positive uniqueness' is exceptionalised and its 'negative abnormality' securitised - a 'normality' which Japan is under constant pressure to emulate through a process of socialisation. On the other hand, there is the 'undemocratic', 'modern' and 'aggressive' China (and North Korea, for that matter), which underscores Japan's own 'normality' as a 'Western', 'democratic', 'postmodern' and 'peaceful' state (cf. Hagström and Hanssen, under review). However, China is also curiously 'normal' in the neo-Bismarckian sense (and so is North Korea) - the securitisation of which further enables the securitisation of Japan's own 'abnormality' or 'weakness', that is, the securitisation of Self - thereby making the political agenda to further 'normalise' or 'remilitarise' Japan conceivable, communicable and indeed coercive (Hagström, 2012).

Despite their very different ontologies, Taku Tamaki and Xavier Guillaume agree that the notion of kokutai ('national polity') — namely, a hierarchical worldview and the associated sense of Japanese 'uniqueness' which is also the gist of nihonjinron - is a more resilient or institutionalised aspect of Japanese identity (Tamaki, 2010), or a 'key narrative matrix' (Guillaume, 2011). However, in my view, this notion risks overemphasising the aspect of 'megalomania' or 'superiority complex' in the way that Japanese identity has been constructed through its differentiation from Others understood to be inferior, and it risks underemphasising the aspect of 'inferiority complex', which has also been a recurring element in processes of differentiation in Japan vis-a-vis the imagined 'West'. Hence, it misses the perhaps inevitably narcissistic swings between the two extremes in the boundary production between Self and Others involving Japan (this is a recurring theme in Morris-Suzuki, 1998; cf. Dale, 1986). Indeed, this is arguably why Japanese identity can be constructed as both 'legitimately exceptional' and 'illegitimately abnormal'/'in need of normalisation' almost at the same time, and why it is sometimes difficult to distinguish proponents of 'normalisation' from advocates of super-normalisation, that is, another kind of exceptionalisation.

\section{Conclusions and implications}

In the post-war period, Japan has continuously been portrayed as 'the abnormal state', both in IR scholarship and in Japanese foreign and security policy debates. Other states have probably been similarly described from time to time (cf. Doty, 1993: 315), but it is no exaggeration to suggest that Japan has been viewed as the 'the abnormal state' par excellence, and particularly in the context of its foreign and security policy. Japan actually resembles Foucault's 'abnormal individuals', because just like them, its alleged 'abnormality' continues to be 'measured against an optimum level of development' 
(Foucualt, 1999: 16) — that is, a norm or standard of 'normality'. Just like them, moreover, Japan is commonly viewed as 'incapable of integrating ... [itself] in the world' (Foucault, 1999: 17). Indeed, Japanese foreign and security policy has continuously been criticised, domestically and by the USA, for not 'contributing' enough, 'taking responsibility' or 'sharing the burden' (Hagström, 2005b). And, just as with Foucault's 'abnormal individuals', Japan's alleged 'abnormality' is constructed through the invocation of "“failure", "inferiority" ... "immaturity", [and] "defective development" (Foucault, 1999: 21). Variations of this narrative have, in fact, been reproduced since the 19th century and recently resurfaced again with much force, revolving especially around former Prime Minister Hatoyama's attempt to renegotiate an accord for the relocation of the US Marine Corps Station Futemna in 2009-2010 (Berkofsky and Hagström, 2010), and Japanese interaction with China over the disputed Senkaku/Diaoyu Islands in the 2010s (Hagström, 2012). Indeed, the 2012 Armitage-Nye Report famously warned that Japan is 'drifting' into 'tier-two status' and asked rhetorically whether Japan is 'content' with this (Armitage and Nye, 2012) - a question which Prime Minister Abe dismissed very clearly: 'Japan is not, and will never be, a Tier-two country' (2013).

Yet, just as Foucault's individuals were defined as 'abnormal' on the basis of traits that were actually rather widespread, one could problematise the notion of Japan's 'abnormality' for overlooking important similarities between Japan and other states. And, just as Foucault's delinquent individuals were constantly subjected to 'techniques of normalisation', or the 'power of normalisation', so too are strong forces deployed to 'normalise' Japan. The discourse on Japan's sometimes looming and sometimes longoverdue 'normalisation' is one of the clearest indicators that the country has been viewed as ultimately 'abnormal', and the discourse on Japan's 'abnormality' can itself be regarded as a technique of normalisation. This article has argued that Japan's abnormalitynormalisation nexus can be understood as an identity discourse. Drawing on a relational concept of identity and particularly the distinction between norm and exception, it has understood the nexus in terms of three identity-producing processes.

First, there is socialisation, or the process whereby the Japanese Self internalises dominant norms, which are also reflected and reproduced in IR theories such as realism. However, these norms typically presuppose prior exceptions, and it is safe to conclude that Japan has been defined as such. This is the gist of the notion that Japan is 'abnormal', which has been reproduced in scholarly, media and policy discourses on Japan's foreign and security policy. These discourses at the same time produce Japan as Other in the international system and the USA as norm - hence, they are central to the construction of a US Self (cf. Campbell, 1994).

Second, there is exceptionalisation, or the process whereby the Japanese Self imagines itself as 'positively' or 'legitimately' different, that is, unique or exceptional. This is how 'pacifism' has been constructed centring on Japan's political left — as a quality making Japan positively different from modern Western territorial states, particularly the USA. To large parts of the political right, in contrast, 'pacifism' is what has made Japan 'negatively' or 'illegitimately' different, that is, 'abnormal'. The goal of the political right, however, is not necessarily to make Japan 'normal'; many of its advocates seem rather to strive for a super-normal — 'beautiful', 'correct' or 'strong' — Japan. In fact, failure to maintain or form 'positive' or 'legitimate' differences, or uniqueness, would in 
a sense be even more detrimental to the reproduction of Japanese identity than a prolonging of 'negative', 'illegitimate' or 'threatening' differences, because without the former, it would be unclear how Japan and Japanese identity could continue to be reproduced (cf. Walker, 2006).

Third, there is securitisation, or the process whereby the Japanese Self tries to protect itself from 'negative', 'illegitimate' or 'threatening' difference. A prominent example is again when the political right tries to secure Japan from its own alleged 'abnormality'. Moreover, this 'abnormality' has been epitomised not primarily by Japan's military shortcomings (as often implied) but - actually quite in line with Schmitt (2004 [1922/1934]: 11) — rather by its inability to declare a state of exception, or go to war. The evidence is that both scholars and Japan's political right have viewed constitutional revision as the ultimate solution of its own 'abnormality' (cf. Huysmans, 2006: 139). This is also seen as the only way to handle the allegedly structural and material threats from China and North Korea, which also materialise through a process of securitisation. Securitisation is usually defined as the social construction of threats to legitimise exceptions 'outside the normal bounds of political procedure' (Buzan et al., 1998: 23-24), but in Japan's case, it is 'normality' — or again super-normality — which is to be restored through an exceptional decision.

In sum, IR research and Japanese foreign and security policy debates have agreed that Japan is 'abnormal' because it has not responded adequately to structural and material factors in the international system. This article, in contrast, has argued that the abnormalitynormalisation nexus has to be understood as a discourse through which Japanese identity is constructed as both Self and Other; and through which the Japanese Self is securitised as Other. The implication is that ideational factors have overruled structural and material ones, because it is on the basis of the former that the latter have been interpreted.

Furthermore, how 'Japan' is inter-subjectively constructed on a scale between 'normal' and 'abnormal' has material consequences. The importance of this discourse has to be understood both in terms of how it enables and constrains Japanese action and through the signals that it transmits to other states about what actions are acceptable and unacceptable - signals which, if they gain resonance and become dominant, define what is conceivable or possible (cf. Digeser, 1992). This is why Davidson's expression of hope quoted in the Introduction - that 'the next time we are tempted to invoke the label "abnormal", rather than appearing familiar, this gesture will become problematic, even difficult' - also has an important bearing on discourses related to Japan (1999: xxv).

Although Japan has not remilitarised nearly as much in the 2000 s as some observers claim, the way in which the country is currently being positioned vis-a-vis some imaginations of China and North Korea and other imaginations of the USA/West might very well forebode more significant steps towards remilitarisation. In terms of foreign and security policy, the imagined USA/West clearly remains the norm, against which Japan is differentiated. China's agglomeration of military capability in recent years could be construed as an attempt to live up to the very same norm, and so in fact could North Korea's development of weapons of mass destruction. Yet, China's security policy is increasingly understood as a problem, and its values and culture are differentiated as 'undemocratic', 'modern' and 'aggressive', and thus 'inferior', thereby emphasising 
Japan's 'normality' as a 'democratic', 'postmodern' and 'peaceful' state. Indeed, both China and North Korea are often represented as dangerously 'abnormal' in their own right (cf. Shim and Nabers, 2013; e.g. Huang, 2013). The securitisation of China and North Korea as threats on such terms concurrently underscores Japan's own 'abnormality' and 'weakness', but it also becomes a powerful argument to further 'normalise' Japanese foreign and security policy through exceptional decisions.

It is quite ironic that Japan's alleged 'peacefulness' in this way becomes an important facet of its 'superiority', which might in the end enable the rescinding of Article 9.

\section{Acknowledgement}

For very helpful comments on earlier drafts of this article, the author would like to thank the editors and anonymous reviewers of the European Journal of International Relations, Stefan Borg, Niklas Bremberg, Alexander Bukh, Amy Catalinac, Johan Eriksson, Karl Gustafsson, Ulv Hanssen, Glenn Hook, Yasu Izumikawa, Björn Jerdén, Peter Katzenstein, Akos Kopper, Tom Lundborg, Akitoshi Miyashita, Paul O'Shea, Chengxin Pan, Kai Schulze, Mike Strausz, Shogo Suzuki, Taku Tamaki and Mikael Weissmann.

\section{Funding}

This research received financial support through fellowships with (a) the Royal Swedish Academy of Letters, History and Antiquities, supported by a grant from the Knut and Alice Wallenberg Foundation, and (b) the Japan Foundation, spent at Kyoto University in 2012.

\section{References}

Abe S (2006) Utsukushii kuni e [Towards a beautiful country]. Tokyo: Bungei shunju.

Abe S (2013) Japan is back. Policy speech at the Center for Strategic and International Studies, 22

February. Available at: http://www.mofa.go.jp/announce/pm/abe/us_20130222en.html

Alderson K (2001) Making sense of state socialization. Review of International Studies 27(3): 415-433.

Araki K (2005) Rachi: ljō na kokka no honshitsu [Abductions: The essence of an abnormal country]. Tokyo: Bensei shuppan.

Arase D (2007) Japan, the active state? Security policy after 9/11. Asian Survey 47(4): 560-583.

Armitage RL and Nye JS (2012) The U.S.-Japan Alliance: Anchoring Stability in Asia. Washington, DC: Center for Strategic and International Studies. Available at: csis.org/files/ publication/120810_Armitage_USJapanAlliance_Web.pdf (accessed 1 May 2013).

Ashizawa K (2008) When identity matters: State identity, regional institution-building, and Japanese foreign policy. International Studies Review 10(3): 571-598.

Befu H (2001) Hegemony of Homogeneity: An Anthropological Analysis of Nihonjinron. Melbourne: Trans Pacific Press.

Berenskoetter F (2010) Identity in International Relations. In: Denemark R (ed.) The International Studies Encyclopedia. Oxford: Wiley-Blackwell, 3595-3611.

Berger TU (1993) From sword to chrysanthemum: Japan's culture of anti-militarism. International Security 17(4): 119-150.

Berger TU (1996) Norms, identity, and national security in Germany and Japan. In: Katzenstein PJ (ed.) The Culture of National Security: Norms and Identities in World Politics. New York: Columbia University Press, 317-356.

Berger TU (1998) Cultures of Antimilitarism: National Security in Germany and Japan. Baltimore, MD: Johns Hopkins University Press. 
Berkofsky A and Hagström L (2010) Futenma and the mobilisation of bias: An alternative perspective on the Japan-US alliance. ISPI Working Paper 38. Milan: Italian Institute for International Studies.

Bukh A (2007) Japan's history textbooks debate: National identity in narratives of victimhood and victimization. Asian Survey 47(5): 683-704.

Bukh A (2009) Identity, foreign policy and the 'Other': Japan's 'Russia'. European Journal of International Relations 15(2): 319-345.

Bukh A (2010) Japan's National Identity and Foreign Policy: Russia as Japan's 'Other'. London: Routledge.

Buruma I (2009 [1994]) The Wages of Guilt: Memories of War in Germany \& Japan. London: Atlantic.

Buzan B, Wæver O and De Wilde J (1998) Security: A New Framework for Analysis. Boulder, CO: Lynne Rienner.

Calder K (1988) Japanese foreign economic policy formation: Explaining the reactive state. World Politics 40(4): 517-541.

Calder K (2003) Japan as a post-reactive state? Orbis 47(4): 605-616.

Campbell D (1994) Policy and identity: Japanese Other/American Self. In: Inayatullah N, Rosow SJ and Rupert M (eds) The Global Economy as Political Space: A Crucial Reader in International Political Economy. Boulder, CO: Lynne Rienner, 147-169.

Campbell D (1998 [1992]) Writing Security: United States Foreign Policy and the Politics of Identity. Manchester: Manchester University Press.

Catalinac AL (2007) Identity theory and foreign policy: Explaining Japan's responses to the 1991 Gulf War and the 2003 U.S. War in Iraq. Politics \& Policy 35(1): 58-100.

Connolly WE (1991) Identity/Difference: Democratic Negotiations of Political Paradox. Minneapolis: University of Minnesota Press.

Constitution of Japan (1946) Available at http://www.kantel.go.jp/foreign/constitution_and goverment/frame_01.html (accessed 18 September 2013).

Crail P and Kimball DG (2012) DPRK now 0-4 on long-range missile tests: Now task is to prevent 3rd nuclear test. Arms control NOW. In: The Blog of the Arms Control Association. Available at: www.armscontrolnow.org/2012/04/12/dprk-now-0-4-on-long-range-missiletests-now-task-is-to-prevent-3rd-nuclear-test/ (accessed 3 December 2012).

Dale PN (1986) The Myth of Japanese Uniqueness. London: Routledge.

Davidson AI (1999) Introduction. In: Foucault M Abnormal. New York: Picador, xvii-xxvi.

Digeser P (1992) The fourth face of power, The Journal of Politics 54(4): 977-1007.

Doty RL (1993) Foreign policy as social construction: A post-positivist analysis of U.S. counterinsurgency policy in the Philippines. International Studies Quarterly 37(3): 297-320.

Epstein, C. (2010). Who speaks? Discourse, the subject and the study of identity in international politics. European Journal of International Relations, 17(2), 327-350.

Flockhart T (2006) 'Complex socialisation': A framework for the study of state socialisation. European Journal of International Relations 12(1): 89-118.

Foucault M (1999) Abnormal. New York: Picador.

Foucault M (2000) The subject and power. In: Faubion JD (ed.) Power. New York: The New Press, 326-348.

Friman RH, Katzenstein PJ, Leheny D et al. (2006) Immovable object? Japan's security policy in East Asia. In: Katzenstein PJ and Shiraishi T (eds) Beyond Japan: The Dynamics of East Asian Regionalism. Ithaca, NY: Cornell University Press, 85-107.

Funabashi Y (1991/1992) Japan and the new world order. Foreign Affairs 70(5): 58-74.

Guillaume X (2011) International Relations and Identity: A Dialogical Approach. London: Routledge. 
Gustafsson K (2011) Narratives and Bilateral Relations: Rethinking the History Issue in Sino-Japanese Relations. PhD Thesis. Stockholm Studies in Politics 139. Stockholm University, Sweden.

Gustafsson K (under review) Identity and recognition: Remembering the post-war in SinoJapanese relations.

Hagström L (2005a) Relational power for foreign policy analysis: Issues in Japan's China policy. European Journal of International Relations 11(3): 395-430.

Hagström L (2005b) Ubiquity of 'power' and the advantage of terminological pluralism: Japan's foreign policy discourse. Japanese Journal of Political Science 6(2): 159-188.

Hagström L (2006) The dogma of Japanese insignificance: The academic discourse on North Korea policy coordination. Pacific Affairs 79(3): 387-410.

Hagström L (2008/2009) Sino-Japanese relations: The ice that won't melt. International Journal 64(1): 223-240.

Hagström L (2009) Normalizing Japan: Supporter, nuisance, or wielder of power in the North Korean nuclear talks. Asian Survey 49(5): 831-851.

Hagström L (2010) The Democratic Party of Japan's security policy and Japanese politics of constitutional revision: A cloud over Article 9? Australian Journal of International Affairs 64(5): $510-525$.

Hagström L (2012) Power shift in East Asia? A critical reappraisal of narratives on the Diaoyu/ Senkaku Islands incident in 2010. Chinese Journal of International Politics 5(3): 267-297.

Hagström L and Hanssen U (under review) The North Korean abduction issue: Emotions, securitisation and the reconstruction of Japanese identity from 'aggressor' to 'victim' and from 'pacifist' to 'normal' country.

Hagström L and Jerdén B (2010) Understanding fluctuations in Sino-Japanese relations: To politicize or to de-politicize the China issue in the Japanese Diet. Pacific Affairs 83(4): 719-739.

Hagström L and Turesson C (2009) Among threats and a 'perfect excuse': Understanding change in Japanese foreign security policy. Korean Journal of Defense Analysis 21(3): 297-314.

Hagström L and Williamsson J (2009) 'Remilitarization', really? Assessing change in Japanese foreign security policy. Asian Security 5(3): 242-272.

Heginbotham E and Samuels RJ (1998) Mercantile realism and Japanese foreign policy. International Security 22(4): 171-203.

Hiranuma T (ed.) (2007) Nihon no seidō [Japan's correct path]. Tokyo: PHP Kenkyūjo.

Hirata K (2008) Who shapes the national security debate? Divergent interpretations of Japan's security role. Asian Affairs: An American Review 35(3): 123-151.

Holland J (2013) Foreign policy and political possibility. European Journal of International Relations 19(1): 49-68.

Hook GD (1988) The erosion of anti-militaristic principles in contemporary Japan. Journal of Peace Research 25(4): 381-394.

Hook GD (1996) Militarization and Demilitarization in Contemporary Japan. London: Routledge.

Hook GD, Gilson J, Hughes CW et al. (2001) Japan's International Relations: Politics, Economics and Security, 1st edn. London: Routledge.

Hopf T (2002) Social Construction of International Politics: Identities \& Foreign Policies, Moscow, 1955 \& 1999. Ithaca, NY: Cornell University Press.

Hosoya Y (2012) Japan's national identity in postwar diplomacy: The three basic principles. In: Rozman G (ed.) East Asian National Identities: Common Roots and Chinese Exceptionalism. Stanford, CA: Stanford University Press, 169-196.

Howe B (2010) Between normality and uniqueness: Unwrapping the enigma of Japanese security policy decision-making. Modern Asian Studies 44(6): 1313-1336.

Huang Y (2013) China, the abnormal great power. Carnegie Endowment for International Peace, 5 March. Available at: http://carnegieendowment.org/2013/03/05/china-abnormal-greatpower/fo53 (accessed 18 September 2013) 
Hughes CW (2007) Not quite the 'Great Britain of the Far East': Japan's security, the U.S.-Japan Alliance and the 'War on Terror' in East Asia. Cambridge Review of International Affairs 20(2): 325-338.

Hughes CW (2009a) Japan's Remilitarisation. Oxford: Routledge; London: International Institute for Strategic Studies.

Hughes CW (2009b) 'Supersizing' the DPRK threat: Japan's evolving military posture and North Korea. Asian Survey 49(2): 291-312.

Huysmans J (2006) International politics of exception: Competing visions of international political order between law and politics. Alternatives: Global, Local, Political 31(2): 135-165.

Hwang Y-J (2010) Japan as 'Self' or 'the Other' in Yoshinori Kobayashi's On Taiwan. China Information 24(1): 75-98.

Igarashi Y (2000) Bodies of Memory. Princeton, NJ: Princeton University Press.

Inoguchi T (1991) Japan's International Relations. Oxford: Westview Press.

Inoguchi T and Bacon P (2006) Japan's emerging role as a 'global ordinary power'. International Relations of the Asia-Pacific 6(1): 1-21.

Izumikawa Y (2010) Explaining Japanese antimilitarism: Normative and realist constraints on Japan's security policy. International Security 35(2): 123-160.

Jackson PT (2004) Hegel's House, or 'People are states too'. Review of International Studies 30(2): 281-287.

Jerdén B and Hagström L (2012) Rethinking Japan's China policy: Japan as an accommodator in the rise of China 1978-2011. Journal of East Asian Studies 12(2): 215-250.

Kano T (1976) Why the search for identity? In: Japan Center for International Exchange (ed.) The Silent Power: Japan's Identity and World Role. Tokyo: Simul Press, 1-10.

Katzenstein PJ (1996a) Cultural Norms and National Security: Police and Military in Postwar Japan. Ithaca, NY: Cornell University Press.

Katzenstein PJ (1996b) Introduction: Alternative perspectives on national security. In: Katzenstein PJ (ed.) The Culture of National Security: Norms and Identities in World Politics. New York: Columbia University Press, 1-32.

Katzenstein PJ (2008) Rethinking Japanese Security: Internal and External Dimensions. London: Routledge.

Katzenstein PJ and Okawara N (1993) Japan's national security: Structures, norms, and policies. International Security 17(4): 84-118.

Kawasaki T (2001) Postclassical realism and Japanese security policy. The Pacific Review 14(2): 221-240.

Kennedy P (1994) Japan: A twenty-first-century power? In: Garby CC and Bullock MB (eds) Japan: A New Kind of Superpower? Baltimore, MD: Johns Hopkins University Press, 193-199.

Kitaoka S (2000) 'Futsū no kuni' e [Towards a 'normal country']. Tokyo: Chūō kōron shinsha.

Kösebalaban H (2008) Torn identities and foreign policy: The case of Turkey and Japan. Insight Turkey 10(1): 5-30.

Lawson S and Tannaka S (2011) War memories and Japan's 'normalization' as an international actor: A critical analysis. European Journal of International Relations 17(3): 405-428.

Layne C (1993) The unipolar illusion: Why new great powers will rise. International Security 17(4): 5-51.

Leheny D (2003) The Rules of Play: National Identity and the Shaping of Japanese Leisure. Ithaca, NY: Cornell University Press.

Lind JM (2004) Pacifism or passing the buck: Testing theories of Japanese security policy. International Security 29(1): 92-121.

Lummis CD [Ramisu CD] (2007) Futsū no kuni ni narimashō [Let's become a normal country]. Tokyo: Ōtsuki shoten.

McCormack G (2004) Remilitarizing Japan. New Left Review 29: 29-45. 
McVeigh BJ (2004) Nationalisms of Japan: Managing and Mystifying Identity. Boulder, CO: Rowman and Littlefield.

Maull HW (1990/1991) Germany and Japan: The new civilian powers. Foreign Affairs 69(5): 91-106.

Midford P (2002) The logic of reassurance and Japan's grand strategy. Security Studies 11(3): $1-43$.

Milliken J (1999) The study of discourse in International Relations: A critique of research and methods. European Journal of International Relations 5(2): 225-254.

Miyashita A (2007) Where do norms come from? Foundations of Japan's postwar pacifism. International Relations of the Asia-Pacific 7(1): 99-120.

Morris-Suzuki T (1998) Re-Inventing Japan: Time, Space, Nation. Armonk, NY: M.E. Sharpe.

Oe K (1995) Japan, the Ambiguous, and Myself: The Nobel Prize Speech and Other Lectures. Tokyo: Kodansha.

Oguma E (2002) A Genealogy of 'Japanese' Self-Images. Melbourne: Trans Pacific Press.

Oros AL (2007) Normalizing Japan: Politics, Identity and the Evolution of Security Practice. Stanford, CA: Stanford University Press.

Orr JJ (2001) The Victim as Hero: Ideologies of Peace and National Identity in Postwar Japan. Honolulu: University of Hawai'i Press.

Otmazgin NK (2008) Contesting soft power: Japanese popular culture in East and Southeast Asia. International Relations of the Asia-Pacific 8(1): 73-101.

Ozawa I (1993) A Blueprint for a New Japan: The Rethinking of a Nation. Tokyo: Kodansha.

Pharr SJ (1993) Japan's defensive foreign policy and the politics of burden-sharing. In: Curtis GL (ed.) Japan's Foreign Policy after the Cold War: Coping with Change. Armonk, NY: M.E. Sharpe, 235-262.

Pyle KB (2007) Japan Rising: The Resurgence of Japanese Power and Purpose. New York: PublicAffairs.

Richardson M (2013) North Korea's nuclear puzzle. Japan Times Online, 24 April. Available at: www.japantimes.co.jp/opinion/2013/04/24/commentary/north-koreas-nuclear-puzzle/ (accessed 29 April 2013).

Rosecrance R (1986) The Rise of the Trading State: Commerce and Conquest in the Modern World. New York: Basic Books.

Rumelili B (2004) Constructing identity and relating to difference: Understanding the EU's mode of differentiation. Review of International Studies 30(1): 27-47.

Ryu Y (2007) The road to Japan's 'normalization': Japan's foreign policy orientation since the 1990s. Korean Journal of Defense Analysis 19(2): 63-88.

Sakamoto R (2007) 'Will you go to war? Or will you stop being Japanese?': Nationalism and history in Kobayashi Yoshinori's Sensoron. In: Heazle M and Knight N (eds) China-Japan Relations in the Twenty-First Century: Creating a Future Past. Cheltenham: Edward Elgar, 75-92.

Samuels RJ (2007) Securing Japan: Tokyo's Grand Strategy and the Future of Asia. Ithaca, NY: Cornell University Press.

Sato K (1997) Same language, same race: The dilemma of Kanbun in modern Japan. In: Dikötter F (ed.) The Construction of Racial Identities in China and Japan. London: Hurst \& Co, 118-135.

Schmitt C (1996 [1932]) The Concept of the Political. Chicago, IL: University of Chicago Press. Schmitt C (2004 [1922/1934]) Political Theology: Four Chapters on the Concept of Sovereignty. Chicago, IL: University of Chicago Press. 
Schulze K (2013) Facing the 'Rise of China': Changes in Japan's Foreign Policy Identity. PhD Thesis, Department for Social Sciences/Institute of East Asian Studies, Duisburg-Essen University.

Sejrup J (2012) Instrumentalized history and the motif of repetition in news coverage of JapanTaiwan relations. Pacific Affairs 85(4): 745-765.

Shibuichi D (2005) The Yasukuni Shrine dispute and the politics of identity in Japan: Why all the fuss? Asian Survey 45(2): 197-215.

Shim D and Nabers D (2013) Imagining North Korea: Exploring its visual representations in international politics. International Studies Perspectives 14(3): 289-306.

Singh B (2008) Japan's security policy: From a peace state to an international state. Pacific Review 21(3): 303-325.

Singh B (2011) Peacekeeping in Japanese security policy: International-domestic contexts interaction. European Journal of International Relations 17(3): 429-451.

Smith AD (1991) National Identity: Ethnonationalism in Comparative Perspective. Reno: University of Nevada Press.

Smith H (2007) Reconstituting Korean security dilemmas. In: Smith H (ed.) Reconstituting Korean Security: A Policy Primer. Tokyo: United Nations University Press, 1-20.

Soeya Y (2005) Nihon no 'midoru pawā' gaikō [Japan's middle power diplomacy]. Tokyo: Chikuma shobō.

Soeya Y (2011) A 'normal' middle power: Interpreting changes in Japanese security policy in the 1990s and after. In: Soeya Y, Tadokoro M and Welch DA (eds) Japan as a 'Normal Country'? A Nation in Search of Its Place in the World. Toronto: University of Toronto Press, 72-97.

Soeya Y, Tadokoro M and Welch DA (2011) Introduction: What is a 'normal country'? In: Soeya Y, Tadokoro M and Welch DA (eds) Japan as a 'Normal Country'? A Nation in Search of Its Place in the World. Toronto: University of Toronto Press, 3-15.

Suzuki S (2005) Japan's socialization into Janus-faced European international society. European Journal of International Relations 11(1): 137-164.

Suzuki S (2007) The importance of 'Othering' in China's national identity: Sino-Japanese relations as a stage of identity conflicts. Pacific Review 20(1): 23-47.

Suzuki S (2009) Civilization and Empire: China and Japan's Encounter with European International Society. London: Routledge.

Tadokoro M (2011) Change and continuity in Japan's 'abnormalcy': An emerging external attitude of the Japanese public. In: Soeya Y, Tadokoro M and Welch DA (eds) Japan as a 'Normal Country'? A Nation in Search of Its Place in the World. Toronto: University of Toronto Press, 38-71.

Tamaki T (2010) Deconstructing Japan's Image of South Korea: Identity in Foreign Policy. Basingstoke: Palgrave Macmillan.

Tamamoto M (2003) Ambiguous Japan: Japanese national identity at century's end. In: Ikenberry GJ and Mastanduno M (eds) International Relations Theory and the Asia-Pacific. New York: Columbia University Press, 191-212.

Tamamoto M (2004) A nationalist's lament: The slippery slope of Koizumi's foreign policy. In: The People vs. Koizumi? Japan-U.S. Relations and Japan's Struggle for National Identity. Asia Program Special Report. Washington, DC: Woodrow Wilson International Center for Scholars, 10-15.

Tamogami T (2011) Hontō wa tsuyoi Nippon [(It is) really a strong Japan]. Tokyo: PHP Kenkyūjo. Tanaka S (1993) Japan's Orient: Rendering Pasts into History. Berkeley: University of California Press. 
Tanter R (2005) With eyes wide shut: Japan, Heisei militarization, and the Bush Doctrine. In: Van Ness P and Gurtov M (eds) Confronting the Bush Doctrine: Critical Views from the AsiaPacific. London: RoutledgeCurzon, 153-180.

Togo K (2012) Japanese national identity: Evolution and prospects. In: Rozman G (ed.) East Asian National Identities: Common Roots and Chinese Exceptionalism. Stanford, CA: Stanford University Press, 147-168.

Tsuchiyama J (2007) War renunciation, Article 9, and security policy. In: Berger TU, Mochizuki MM and Tsuchiyama J (eds) Japan in International Politics: The Foreign Policies of an Adaptive State. Boulder, CO: Lynne Rienner, 47-74.

Twomey CP (2000) Japan, the circumscribed balancer: Building on defensive realism to make predictions about East Asian security. Security Studies 9(4): 167-205.

Walker RBJ (2006) The double outside of the modern international. Ephemera: Theory and Politics in Organization 6(1): 56-69.

Waltz KN (1993) The emerging structure of international politics. International Security 18(2): $44-79$.

Waltz KN (2000) Structural realism after the Cold War. International Security 25(1): 5-41.

Watanabe Y and McConnell D (2008) Introduction. In: Watanabe Y and McConnell D (eds) Soft Power Superpowers: Cultural and National Assets of Japan and the United States. Armonk, NY: M.E. Sharpe, xvii-xxxii.

Welch DA (2011) Embracing normalcy: Toward a Japanese 'national strategy'. In: Soeya Y, Tadokoro M and Welch DA (eds) Japan as a 'Normal Country'? A Nation in Search of Its Place in the World. Toronto: University of Toronto Press, 16-37.

Wendt A (1992) Anarchy is what states make of it: The social construction of power politics. International Organization 46(2): 391-425.

Wendt A (1999) Social Theory of International Politics. Cambridge: Cambridge University Press. Williams MC (1998) Identity and the politics of security. European Journal of International Relations 4(2): 204-225.

Wodak R, De Cillia R, Reisigl M et al. (2009 [1999]) The Discursive Construction of National Identity, 2nd edn. Edinburgh: Edinburgh University Press.

Yachi S (2009) Gaikō no senryaku to kokorozashi [The strategy and aspiration of diplomacy]. Tokyo: Sankei shinbun shuppan.

Yoshino K (1992) Cultural Nationalism in Contemporary Japan. London: Routledge.

Zarakol A (2010) Ontological (in)security and state denial of historical crimes: Turkey and Japan. International Relations 24(1): 3-23.

Zarakol A (2011) After Defeat: How the East Learned to Live with the West. Cambridge: Cambridge University Press.

Zehfuss M (2001) Constructivism and identity: A dangerous liaison. European Journal of International Relations 7(3): 315-348.

\section{Author biography}

Linus Hagström is Associate Professor of Political Science and Senior Research Fellow at the Swedish Institute of International Affairs, Sweden. He is also Research Fellow at the Royal Swedish Academy of Letters, History and Antiquities, supported by a grant from the Knut and Alice Wallenberg Foundation. Hagström is the author of Japan's China Policy: A Relational Power Analysis (Routledge, 2005) and he has most recently published articles in the Journal of East Asian Studies, the Chinese Journal of International Politics, the Australian Journal of International Affairs, Pacific Affairs, Asian Survey and Asian Security. 